\title{
クロムメッキ夜中の $\mathrm{SO}_{4}$ の自動制御
}

\author{
小 西 三 郎* ・ 久保田 保 隆** \\ Chromium Plating Bath for Self-regulating $\mathrm{SO}_{4}$ \\ Chromium Plating from Low Concentration $\mathrm{CrO}_{3}$ Baths (Part 8) \\ Saburo KONISHI and Yasutake KUBOTA
}

The self-regulation of sulfate concentration by the addition of $\mathrm{Sr}^{2+}$ to a chromium plating bath saturated with $\mathrm{SrSO}_{4}$ was studied. The following results were obtained: (1) Since $\mathrm{SrSO}_{4}$ is a strong acid salt, the solubility of $\mathrm{SrSO}_{4}$ in low pH solution such as a chromium plating bath was not much higher than that in its aqueous solution. (2) $\mathrm{The}^{\mathrm{SO}_{4}}$ concentration could freely be regulated by the addition of $\mathrm{SrCO}_{3}$ to the chromium plating bath. (3) The decrease in the solubility of $\mathrm{SrCO}_{3}$ conformed to "common-ion effect" in the chromium plating bath, but not in the aqueous solution. It would be more clear by assuming activity instead of concentration. Namely, the ionic strength was higher and steady in the chromium plating bath and was supposed to be proportional to $\mathrm{CrO}_{3}$ concentration; but it was changeable in the aqueous solution. (4) For example, the solubility of $\mathrm{SrSO}_{4}$ (as $\mathrm{SO}_{4}$ ) was 1.4 $\mathrm{g} / \mathrm{l}$ in chromium plating bath containing $50 \mathrm{~g} / \mathrm{l}$ of $\mathrm{CrO}_{3}$ at $55^{\circ} \mathrm{C}$. When $\mathrm{SrCO}_{3}$ of $6.0 \mathrm{~g} / \mathrm{l}$ was added to the bath, the $\mathrm{SO}_{4}$ concentration became $0.5 \mathrm{~g} / \mathrm{l}$, by which the plating bath for self-regulating $\mathrm{SO}_{4}$ was prepared.

\section{1. ま え がき}

$\mathrm{SO}_{4}{ }^{2-}$ は現在のクロムメッキ液に拈いては必要かくべ からざる触媒であり, 現在使用されている光沢クロムメ ッキ浴には必ず $\mathrm{SO}_{4}{ }^{2-}$ が添加されている。われわれが研 究中の低濃度クロムメッキ液に括いて子例外ではない 1) 5)。 $\mathrm{SO}_{4}{ }^{2-}$ 自動制御クロムメッキ浴については特許 ${ }^{6)}$, 7)，その他にも発表8),9)されているがまとまった報告は 皆無である。

したがって $\mathrm{SO}_{4}{ }^{2-}$ の自動制御クロムメッキ浴について くわしく検討し，これの低濃度クロムメッキ浴への応用 を試みた。

\section{2. 実 験 方 法}

\section{2-1 クロムメッキ液中での硫酸ストロンチウムの}

\section{溶解度の測定手順}

これは前報 ${ }^{10)}$ の操作方法とまったく同様であり，ただ

†低濃度クロム酸溶液からのクロムメッキに関する研究 （第 8 報），前報(第 7 報）：金属表面技術, 24, 386(1973)

* 大阪府立工業技術研究所 (大阪府東大阪市高井田中 1 -38)

Industrial Research Institute Osaka Prefecture

**奥野製薬工業秼（大阪府大阪市城東区放出町中1-38）

Okuno Chemical Industry Co., Ltd.
使用薬品がフッ化カルシウムは硫酸ストロンチウムに, 水酸化カルシウムが炭酸ストロンチウムに, そして塩化 カルシウムが塩化ストロンチウムに変わっただけである のでくわしくは前報 ${ }^{10)}$ を参照されたい。

\section{2-2 $\mathrm{SO}_{4}{ }^{2-}$ の定旦方法}

$\mathrm{SO}_{4}^{2-}$ の定量は分光光電光度計を使用し, 発表されて いるクロムメッキ液中の $\mathrm{SO}_{4}{ }^{2-}$ の比濁分析法 ${ }^{11)}$ を改良し た方法で行なった。この方法は今回の実験のように試料 溶液中の $\mathrm{SO}_{4}{ }^{2-}$ 濃度が非常にうすい場合があったり，ま た同一試料溶液から順次数多くの溶液を採取しなければ ならない場合には, 従来からよく行なわれてきた重量法 ${ }^{12)}$, 容量法 ${ }^{13)}$ やとの他の方法 ${ }^{14)}$ では試料溶液の採取量が 多いので問題である。この点この比濁法では試料溶液の 採取量は少ないので都合がよく，また今回の実験のよう に分析試料数が多い場合には重量法や容量法に比べて非 常に有利である。

\section{3. 実験結果および考察}

\section{3一1 クロムメッキ液中の硫酸ストロンチウムの 溶解度}

図 1 の実線はクロム酸濃度が $50 \sim 400 \mathrm{~g} / l$ 溶液で浴温 を変化した場合の硫酸ストロンチウムの溶解度を示して いる。これからも明らかなようにクロム酸溶液中の硫酸 


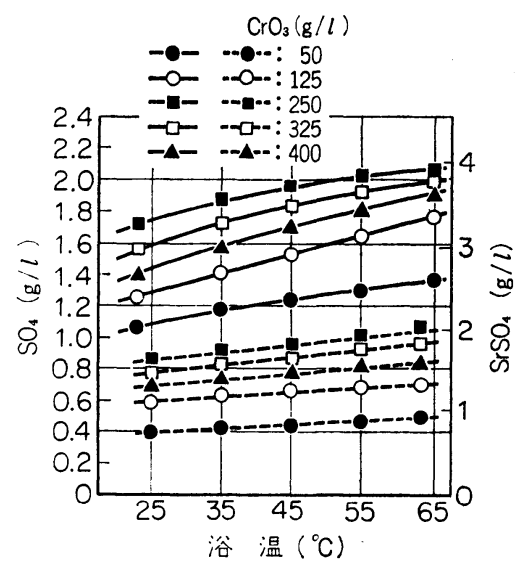

図 1 クロムメッキ液中（実線）およびこれに $6 \mathrm{~g} / l$ の $\mathrm{SrCO}_{3}$ を添加したクロムメッキ 液 (破線) 中での $\mathrm{SrSO}_{4}$ の溶解度

ストロンチウムの溶解度は浴温の上昇ととるに増加する 傾向が見られる。またクロム酸濃度が $250 \mathrm{~g} / l$ 前後で最 大の溶解度を示し，これよりもクロム酸濃度が高くても 低くても減少していることは前報 ${ }^{10)} の フ ッ$ 化カルシウム と同様の傾向である。

クロム酸溶液中の硫酸ストロソチウムの溶解度に関す るくわしい報告は見当たらないが, Stareck の特許7)に よればクロム酸 $250 \mathrm{~g} / l$ で浴温が $44^{\circ} \mathrm{C}$ における溶解度は $\mathrm{SO}_{4}{ }^{2-}$ として $2.1 \mathrm{~g} / l$ であり, Gabriel ${ }^{9)}$ の報告ではクロ ム酸 $250 \mathrm{~g} / l$ で浴温が $55^{\circ} \mathrm{C}$ では $\mathrm{SrSO}_{4}$ として $4.4 \mathrm{~g} / l$ $\left(\mathrm{SO}_{4}{ }^{2-}\right.$ とすれば, $2.3 \mathrm{~g} / l$ に相当する)であり, 同じ条件 のわれわれの実験結果よりるやや多い。

またカルシウムを使用したテトラクロメート浴の自動 制御浴を開発する目的で, クロム酸溶液中の硫酸カルシ ウムの溶解度が測定されている8 が，その結果に打いて 女硫酸カルシウムの最大溶解度はクロム酸濃度が 250 $\mathrm{g} / l$ 付近にあり, $20^{\circ} \mathrm{C}$ に打ける硫酸カルシウムの溶解度 は約 $20 \mathrm{~g} / l\left(\mathrm{SO}_{4}{ }^{2-}\right.$ とすれば14g/l) であり，これよりも クロム酸濃度が高くても低くても低下している。

硫酸ストロンチウムの水溶液中での発表されている溶 解度 ${ }^{15)}$ は常温で $0.0114 \mathrm{~g} / \mathrm{H}_{2} \mathrm{O} 100 \mathrm{~g}$ であるが，これは約 $0.114 \mathrm{~g} / l$ になる。これはクロム酸 $250 \mathrm{~g} / l$ 中の溶解度の 約 $1 / 5$ であり, 硫酸ストロンチウムの場合には前報 ${ }^{10)}$ の フッ化カルシウムの場合ほどクロムメッキ液中でもそれ ほど溶解度が大きく増加していない。これは前報でもく わしく説明したように硫酸ストロンチウムは強酸の塩で あるためである。

サージャント浴の標準浴組成は,

$$
\begin{array}{ll}
\mathrm{CrO}_{3} & 250 \mathrm{~g} / l \\
\mathrm{H}_{2} \mathrm{SO}_{4} & 2.5 \mathrm{~g} / l
\end{array}
$$

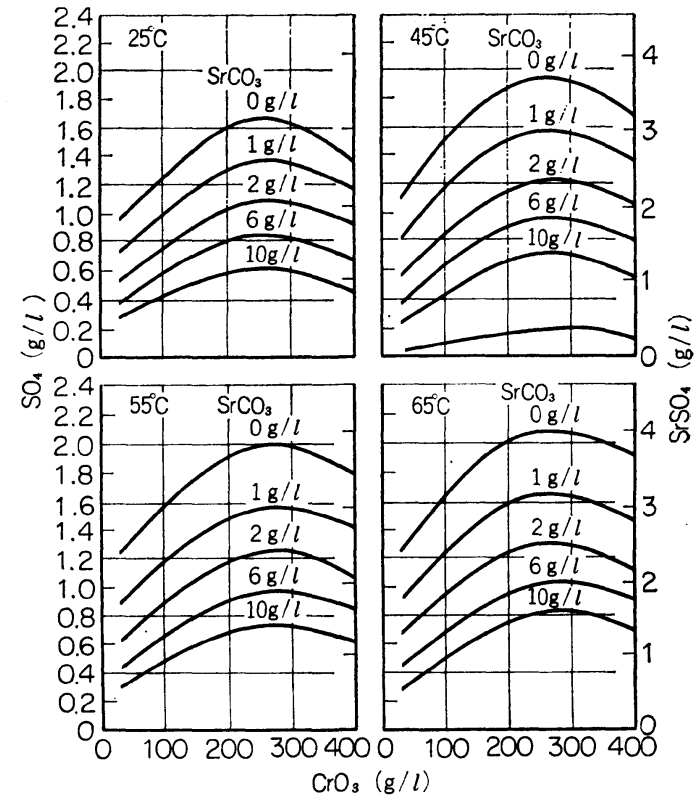

図 $2 \mathrm{SrCO}_{3}$ を添加したクロムメッキ液中の $\mathrm{SrSO}_{4}$ の溶解度の変化

であるので, クロム酸 $250 \mathrm{~g} /$ / のクロムメッキ液ではこれ に多量の硫酸ストロンチウムを添加しても適正浴温 (45 〜 55 ${ }^{\circ} \mathrm{C}$ )では $\mathrm{SO}_{4}{ }^{2-}$ 濃度は不足していることは図 1 から も明らかである。しかしクロム酸濃度が $250 \mathrm{~g} / l$ のロム メッキ浴においても $\mathrm{SO}_{4}{ }^{2-} / \mathrm{CrO}_{3}$ の比が ${ }^{1 / 100}$ 以下の比較 的 $\mathrm{SO}_{4}{ }^{2-}$ 濃度の低い浴では“ツキマワリ”が良好なク口 ムメッキが得られることはよく知られている。たとえば ケイフッ化物 ${ }^{16)}$ やン化物 ${ }^{17)}$ の添加浴がその例であり, このよらなクロムメッキ液では過剰の硫酸ストロンチウ ムの添加のみで，ほぼ適当な $\mathrm{SO}_{4}{ }^{2-}$ 濃度のクロムメッキ 液となる。この場合 $\mathrm{SO}_{4}^{2-}$ が不足すれば溶解していない 硫酸ストロンチウムより $\mathrm{SO}_{4}{ }^{2-}$ が補給されるけれども過 剩の $\mathrm{SO}_{4}{ }^{2-}$ の混入に対してはこれを制御することはでさ ない。このような $\mathrm{SO}_{4}{ }^{2-}$ の制御とより最適の $\mathrm{SO}_{4}{ }^{2-}$ 濃度 の保持にはつぎに述べるようなストロンチウム塩の添加 による制御が必要である。

\section{3-2 ストロンチウムの添加による $\mathrm{SO}_{4}{ }^{2-}$ の溶解度の 低下}

図 1 で破線で示したのは硫酸ストロンチウム飽和のク ロムメッキ液に $6.0 \mathrm{~g} / l$ の炭酸ストロンチウムを添加し た場合のメッキ液中に溶解している $\mathrm{SO}_{4}{ }^{2-}$ の濃度を示し ている。これからも明らかなよらに，ストロンチウムの 添加によって $\mathrm{SO}_{4}{ }^{2-}$ 濃度は相当に減少し，また浴温の影 響はストロンチウムの無添加に比べて少なくなっている ことは $\mathrm{SO}_{4}{ }^{2-}$ の自動制御浴開発上有利である ${ }^{10)}$ 。

図 2 は各浴温での炭酸ストロンチウムの添加量による 


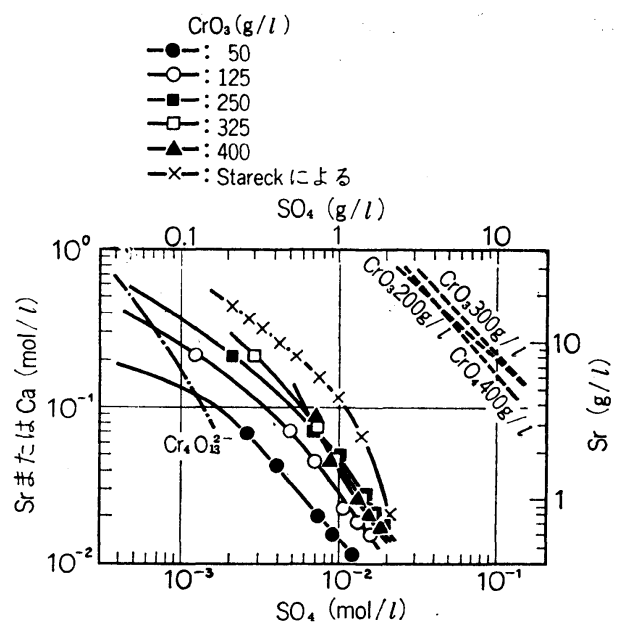

図 3 クロムメッキ液中の $\mathrm{SrSO}_{4}$ また $\mathrm{CaSO}_{4}$ (破 線)に $\mathrm{SrCO}_{3}$ またはCa(OH) 2 を加えた場合の $\mathrm{SrSO}_{4}$ をた $\mathrm{CaSO}_{4}$ の溶解度の変化

クロムメッキ液中の $\mathrm{SO}_{4}{ }^{2-}$ 濃度の変化を示している。こ の図からいろいろのクロムメッキ液での最適 $\mathrm{SO}_{4}{ }^{2-}$ 濃度 に自動制御するための炭酸ストロンチウムの添加量を読 み取ることがでさる。現在われわれが実験中の低濃度ク ロムメッキ液の推奖浴組成は ${ }^{1) ~ 5), ~}$

$\begin{array}{lr}\mathrm{CrO}_{3} & 50 \mathrm{~g} / l \\ \mathrm{H}_{2} \mathrm{SO}_{4} & 0.5 \mathrm{~g} / l \\ \mathrm{Na}_{2} \mathrm{SiF}_{6} & 0.5 \mathrm{~g} / l\end{array}$

であり, 浴温は $50^{\circ} \mathrm{C}$ 前後で使用するのがよいので, 溶解 度以上の硫酸ストロンチウムと $5 \mathrm{~g} / l$ の炭酸ストロンチ ウムを添加すれば $\mathrm{SO}_{4}{ }^{2-}$ 濃度が $0.5 \mathrm{~g} / l$ 自動制御浴とな る。

堀 ${ }^{18)}$ が発表しているマイクロクラッククロムメッキ液 は45ㄷで使用され，浴組成の一例は，
$\mathrm{CrO}_{3}$
$190 \mathrm{~g} / \mathrm{l}$
$\mathrm{H}_{2} \mathrm{SO}_{4}$
1. $1 \mathrm{~g} / \mathrm{l}$
$\mathrm{Na}_{2} \mathrm{SiF}_{6}$
$5.0 \mathrm{~g} / \mathrm{l}$

であるので, 溶解度以上の硫酸ストロンチウムと $4 \mathrm{~g} / l$ の炭酸ストロンチウムを添加すればよいことがわかる。

$45^{\circ} \mathrm{C}$ に拈けるこれらの関係を $\mathrm{SO}_{4}^{2-}$ とストロンチウム のモル濃度の対数で表わしたのが図 3 である。これには $\mathrm{Stareck}^{7)}$ のクロム酸濃度が $250 \mathrm{~g} / l$ で浴温が $44^{\circ} \mathrm{C}$ にお ける実験結果と Dominikov ${ }^{8)}$ のクロム酸濃度が 200 $400 \mathrm{~g} / l$ 浴でのカルシウムの添加による $\mathrm{SO}_{4}{ }^{2-}$ 濃度の減 少も記入した。これらの絶対值は異なっているけれどす ほぼ同様の傾向を示していることがわかる。

図 4 は硫酸ストロンチウムの飽和水溶液に塩化ストロ ソチウムを添加していった場合の硫酸ストロンチウムの 溶解度の減少を示している。破線で示したのは発表され

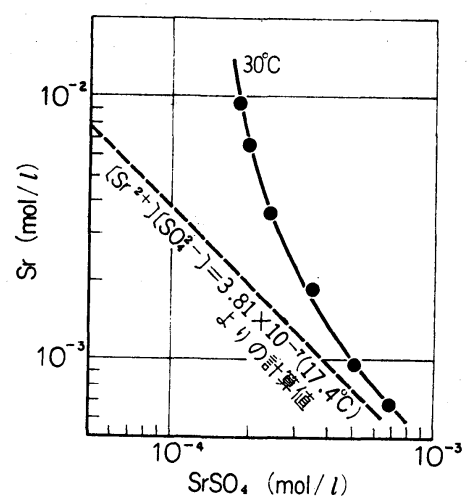

図 $4 \mathrm{SrSO}_{4}$ 飽和水溶液に $\mathrm{SrCl}_{2}$ を添加した場合の $\mathrm{SrSO}_{4}$ の溶解度の変化

ている硫酸ストロンチウム溶解度積 ${ }^{15)}\left[\mathrm{Sr}^{2+}\right]\left[\mathrm{SO}_{4}{ }^{2-}\right]$ $=3.81 \times 10^{-7}\left(17.4^{\circ} \mathrm{C}\right)$ より計算した硫酸ストロンチウ ムの溶解度の減少である。この場合ストロンチウムの添 加量が少ないときには実験値と計算値は比較的よく一致 しているけれどもストロンチウムの添加量が多くなるに したがいその差は大きくなっている。一般に質量作用の 法測は濃度ではなく活量にしたがらすのであるが，この 場合の計算は活量ではなく濃度を使用したために，この よらな結果が得られたものと考えられる。したがって活

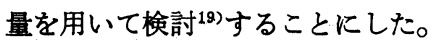

硫酸ストロンチウムの溶解度積を $S$ とすれば

$\left[\mathrm{Sr}^{2+}\right]\left[\mathrm{SO}_{4}^{2-}\right]=S$.

である。これを濃度 $C$ と活量係数 $f$ を用いてあらわせば

$$
C_{\mathrm{Sr}^{2+}}{ }^{2+} f_{\mathrm{Sr}^{2+}}{ }^{2+} \cdot C_{\mathrm{SO}_{4}}{ }^{2-} f_{\mathrm{SO}_{4}}{ }^{2-}=S
$$

または

$$
C_{\mathrm{Sr}^{2+}} \cdot C_{\mathrm{SO}_{4}{ }^{2-}}=\frac{S}{f_{\mathrm{Sr}^{2+}} \cdot f_{\mathrm{SO}_{4}{ }^{2-}}}
$$

となる。硫酸ストロンチウムのような溶解度の低い飽和 水溶液ではイオン強度は小さいので, $f_{\mathrm{Sr}^{2+}}{ }^{2+}$ よび $f_{\mathrm{SO}_{4}}{ }^{2-}$ はほとんど1に近いが，いまここに共通イオンを持たな い電解質を添加すれば電解質のイオン価, 性質, 濃度およ び共存するそ、他のイオンによっても異なるがイオン強 度の増加によって活量係数は極少にまで減少したのちら たたび増加する。ところが硫酸ストロンチウムの溶解度 積 $S$ は定であるので活量係数の減少にともない $C_{\mathrm{Sr}^{2+}}$ $\mathrm{CSO}_{\mathrm{SO}^{2-}}{ }^{2-}$ 増加しなければならない。これは “塩類効果” とすいわれる ${ }^{20)}$ 現象である。

いま硫酸ストロンチウムの飽和水溶液に共通イオンを 持たない塩化カリウムまたは塩化カルシウム，フッ化カ ルシウムの飽和水溶液に同じく共通イオンを持たない塩 化カリウムまたは塩化バリウムを加えた場合の硫酸スト ロソチウム, フッ化カルシウムの溶解度の増加はわれわ 
れの実験では表 1 ，表 2 に示したようになった。またこ れらはつぎのようにして計算することもできる。

たとえば硫酸ストロンチウムの飽和水溶液に塩化カリ ウムを加えた場合の硫酸ストロンチウムの溶解度の增加 はつぎのようになる。

この計算を行ならためにはイオン強度と活量保数の関 係が必要である。溶液のイオン強度 $I$ は次式により求め ることができる ${ }^{19) 。}$

$$
I=\frac{1}{2} \Sigma_{Z n^{2}} C_{n}
$$

イオン強度と活量保数の関係 ${ }^{199}$ は,

$I<0.02$ より小さいときには $f_{n}$ は，

$$
-\log f_{n}=0.5 z n^{2} \sqrt{I}
$$

$0.02<I<0.2$ 場合には,

$$
-\log f_{n}=\frac{0.5 z n^{2} \sqrt{I}}{1+\alpha \cdot 0.33 \cdot 10^{8} \sqrt{I}}
$$

となるが， $\alpha$ はcm単位で測定した問題のイオンの平均半
径であるが，この大きさはほとんど $3 \cdot 10^{-8} \mathrm{~cm}$ と考兄 てさしつかえないので，この計算では次式を用いて行な らことにした。

$$
-\log f_{n}=\frac{0.5 z n^{2} \sqrt{I}}{1+\sqrt{I}}
$$

われわれが測定した $25^{\circ} \mathrm{C} に$ 打ける硫酸ストロンチウム の水溶液での溶解度 $S_{0}$ は表1に示したように, 6. $20 \times 10^{-4}$ $\mathrm{mol} / l$ であったので, この場合のイオン強度は(4)より

$I=1 / 2\left(2^{2} \times 6.2 \times 10^{-4}+2^{2} \times 6.2 \times 10^{-4}\right)=2.48 \times 10^{-3}$ したがって(5)より,

$$
-\log f_{\mathrm{Sr}^{2+}}=-\log f_{\mathrm{SO}_{4}}{ }^{2-}=0.5 \times 2^{2} \sqrt{2.48 \times 10^{-3}}
$$

ゆ兄に $\quad f_{\mathrm{Sr}^{2+}}=f_{\mathrm{SO}_{4}}{ }^{2-}=0.795$

したがって硫酸ストロンチウムの飽和水溶液の溶解度積 は

$$
\begin{aligned}
& C_{\mathrm{Sr}^{2+}}{ }^{2+} f_{\mathrm{Sr}^{2+}} \cdot C_{\mathrm{SO}^{4}}{ }^{2-} \cdot f_{\mathrm{SO}^{2}}{ }^{2-}=\left(6.2 \times 10^{-4}\right)^{2}(0.795)^{2} \\
& \quad=2.44 \times 10^{-7}
\end{aligned}
$$

となる。この硫酸ストロンチウ

表 1 共通イオンをもたない塩類の添加による $\mathrm{SrSO}_{4}$ の溶解度の増加

\begin{tabular}{c|c|c|c|c|c|c}
\hline \hline \multirow{2}{*}{ 系 } & \multirow{2}{*}{ 添加塩類 } & $\mathrm{mol} / l$ & \multicolumn{2}{|c|}{ 実 測 } & 值. & \multicolumn{2}{|c}{ 計 算 值 } \\
\cline { 3 - 7 } & & & $\mathrm{SrSO}_{4}(\mathrm{~mol} / l)$ & $S / S_{o}$ & $\mathrm{SrSO}_{4}(\mathrm{~mol} / l)$ & $S / S_{o}$ \\
\hline $\mathrm{SrSO}_{4}-\mathrm{KCl}$ & $\mathrm{KCl}$ & 0 & $6.20 \times 10^{-4}$ & 1.00 & $6.20 \times 10^{-4}$ & 1.00 \\
& & $10^{-3}$ & $6.52 \times 10^{-4}$ & 1.05 & $6.48 \times 10^{-4}$ & 1.05 \\
& & $5 \times 10^{-3}$ & $6.90 \times 10^{-4}$ & 1.11 & $7.38 \times 10^{-4}$ & 1.19 \\
& & $10^{-2}$ & $7.96 \times 10^{-4}$ & 1.28 & $8.27 \times 10^{-4}$ & 1.33 \\
& & $5 \times 10^{-2}$ & $1.03 \times 10^{-3}$ & 1.67 & $1.17 \times 10^{-3}$ & 1.89 \\
\hline $\mathrm{SrSO}_{4}-\mathrm{CaCl}_{2}$ & $\mathrm{CaCl}_{2}$ & 0 & $6.21 \times 10^{-4}$ & 1.00 & $6.21 \times 10^{-4}$ & 1.00 \\
& & $10^{-3}$ & $7.34 \times 10^{-4}$ & 1.18 & $7.00 \times 10^{-4}$ & 1.13 \\
& & $4 \times 10^{-3}$ & $8.80 \times 10^{-4}$ & 1.42 & $8.66 \times 10^{-4}$ & 1.39 \\
& & $7 \times 10^{-3}$ & $9.68 \times 10^{-4}$ & 1.56 & $1.01 \times 10^{-3}$ & 1.63 \\
& & $10^{-2}$ & $1.16 \times 10^{-3}$ & 1.71 & $1.14 \times 10^{-3}$ & 1.84 \\
\hline \hline
\end{tabular}

表 2 共通イオンをもたない塩類の添加による $\mathrm{CaF}_{2}$ の溶解度の增加

\begin{tabular}{c|c|c|c|c|c|c}
\hline \hline \multirow{2}{*}{ 系 } & \multirow{2}{*}{ 添加塩類 $\mathrm{mol} / l$} & \multicolumn{2}{|c|}{ 実測 值 } & \multicolumn{2}{|c}{ 計 算 值 } \\
\cline { 3 - 7 } & \multicolumn{2}{|c|}{$\mathrm{CaF}_{2}(\mathrm{~mol} / \mathrm{l})$} & $S / S_{o}$ & $\mathrm{CaF}_{2}(\mathrm{~mol} / l)$ & $S / S_{o}$ \\
\hline $\mathrm{CaF}_{2}-\mathrm{KCl}$ & $\mathrm{KCl}$ & 0 & $2.07 \times 10^{-4}$ & 1.00 & $2.07 \times 10^{-4}$ & 1.00 \\
& & $10^{-3}$ & $2.14 \times 10^{-4}$ & 1.03 & $2.15 \times 10^{-4}$ & 1.04 \\
& & $5 \times 10^{-3}$ & $2.36 \times 10^{-4}$ & 1.12 & $2.34 \times 10^{-4}$ & 1.13 \\
& & $10^{-2}$ & $2.40 \times 10^{-4}$ & 1.16 & $2.46 \times 10^{-4}$ & 1.19 \\
& & $5 \times 10^{-2}$ & $3.77 \times 10^{-4}$ & 1.82 & $3.00 \times 10^{-4}$ & 1.45 \\
\hline $\mathrm{CaF}_{2}-\mathrm{BaCl}_{2}$ & $\mathrm{BaCl}_{2}$ & 0 & $2.05 \times 10^{-4}$ & 1.00 & $2.05 \times 10^{-4}$ & 1.00 \\
& & $10^{-3}$ & $2.14 \times 10^{-4}$ & 1.04 & $2.28 \times 10^{-4}$ & 1.11 \\
& & $4 \times 10^{-3}$ & $2.17 \times 10^{-4}$ & 1.06 & $2.50 \times 10^{-4}$ & 1.22 \\
& & $7 \times 10^{-3}$ & $2.32 \times 10^{-4}$ & 1.13 & $2.60 \times 10^{-4}$ & 1.27 \\
& & $10^{-2}$ & $2.70 \times 10^{-4}$ & 1.32 & $2.82 \times 10^{-4}$ & 1.37 \\
\hline \hline
\end{tabular}

ムの活量係数を用い，たとえば $5 \times 10^{-3} \mathrm{~mol} / l$ の塩化カリウム を添加した場合の硫酸ストロン チウムの溶解度 $S$ はつぎのよう にして求めることができる。

このような溶液でのイオン強 度は硫酸ストロンチウムと塩化 カリウムの拉の拉ののイオン強 度の和であるので,

$$
\begin{aligned}
& I=2.48 \times 10^{-3}+1 / 2\left(5 \times 10^{-3}\right. \\
& \left.\quad+5 \times 10^{-3}\right)=7.48 \times 10^{-3} \\
& \text { したがって(5)より, } \\
& -\log f_{\mathrm{Sr}^{2+}}=-\log f_{\mathrm{SO}_{4}}{ }^{2-}=0.5 \\
& \quad \times 2^{2} \sqrt{7.48 \times 10^{-3}}
\end{aligned}
$$

ゆ之に $f_{\mathrm{Sr}^{2+}}=f_{\mathrm{SO}_{4}{ }^{2-}}=0.671$

したがって(3)より，

$$
\begin{gathered}
C_{\mathrm{Sr}^{2+}} \cdot C_{\mathrm{SO}^{2-}}{ }^{2-}=\frac{2.44 \times 10^{-7}}{(0.671)^{2}} \\
\quad=5.42 \times 10^{-7}
\end{gathered}
$$

ゆえに, $S=\sqrt{5.42 \times 10^{-7}}$

$$
=7.38 \times 10^{-4}
$$

したがって, $S / S_{0}=7.38 \times 10^{-4}$

$$
/ 6.2 \times 10^{-4}=1.19
$$

となる。他の場合においてもこ れと同様にして計算することが できる。これらの計算結果は表 1 と表 2 に示したが，実測值と 計算値は比較的よく一致してお り，上記の理論が正しいことが わかる。すなわち難溶性塩の溶 
解度にその溶液のイオン強度が高くなれば増加するとい らことになる。この現象は共通イオンによっても成立す るので, (共通イオンの添加によってもイオン強度は増 加するので）共通イオンによる硫酸ストロンチウムの溶 解度の減少は制限されることになり, 図4のよらな結果 となる。このことは前報10)のフッ化カルシウムの場合に もあてはまることは事実であるが，この場合には上記の 計算からも明らかなよらに, 硫酸ストロンチウムに比べ てイオン強度が小さいので, この塩類効果によるフッ化 カルシウムの溶解度は少なかっただけである。

クロム酸溶液中のストロンチウムの添加による硫酸ス トロンチウムの溶解度の変化については, クロム酸濃度 は高いのでイオン強度も高く, この中の硫酸ストロンチ ウムや添加ストロンチウム塩の濃度はクロム酸濃度に比 ベれば小さいので溶液全体のイオン強度は大きく変化し ないので, 活量係数の変化は小さいものと考えられるか ら, 活量はいつも濃度に比例するとして, クロム酸濃度 を活量の目安に利用することができる。これは図 3 から も明らかなように, $\mathrm{pH}$ があまり変化しないテトラクロ

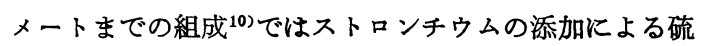
酸ストロンチウムの溶解度の減少は濃度を用いて質量作 用の法則からの計算值とよく一致していることからるわ かる。

けれどすより高いストロンチウム濃度に打いては硫酸 ストロンチウムの溶解度は上記の計算值よりもより減少 している。これは前報 ${ }^{10)} の フ ッ$ 化カルシウムの場合に拉 いても見られた現象であり，前にも述べたようにクロム 酸溶液ではストロンチウムの添加は炭酸ストロンチウム で行なっているので, これらに相当するクロメートが生 成し溶液の $\mathrm{pH}$ が上昇しているためである。

クロム酸溶液中での難溶性塩の溶解度はその塩の性質 と溶液の $\mathrm{pH}$ に左右されることは前報10)で述べたが，こ れだけの説明では不十分であった。しかしこの不十分な ところは “塩類効果”によって補足することができる。

クロム酸溶液中への難溶性塩の溶解度は比較的溶解度 の高かったケイフッ化ナトリウムを除き，クロム酸濃度 が $250 \mathrm{~g} / l$ 付近で最大の溶解度を示した。またいろいろ のクロム酸濃度の溶液においてもケイフッ化物を除いて はクロム酸濃度が $250 \mathrm{~g} / l$ 以下の溶液では, その溶液の $\mathrm{pH}$ から計算した溶解度よりも高かった

これらの現象はつぎのように説明することができる。 すなわちクロム酸濃度が $250 \mathrm{~g} / l$ 以下の溶液では濃度の 増加にしたがいイオン強度は高くなるために活量係数は 減少するので, その溶液の $\mathrm{pH}$ から計算した溶解度より も高くなったものと考えられる。またクロム酸濃度が $250 \mathrm{~g} / l$ 以上での溶解度の低下についてはクロム酸の活 量係数はクロム酸濃度が $250 \mathrm{~g} / l$ 付近を極少として，ふ
たたび上昇するためであると考えられる。ケイフッ化物 の挙動が他の塩類と異なっていた点については, ケイフ ッ化ナトリウムでは水溶液中での溶解度が高かったこ と, $\mathrm{SiF}_{6}{ }^{2-}$ の錯イオンはさらに複雑に解離するので，ク ロム酸濃度以外の条件でイオン強度が高くなること, さ らにケイフッ化物の活量係数の極少は比較的濃度の低い ところにあるのではないかと考えられることなどが複雑 に作用していると考えられる。

\section{4. 結 論}

クロムメッキ液における $\mathrm{SO}_{4}{ }^{2-}$ の自動制御浴について 実験を行ないつぎのような結果を得た。

1）クロムメッキ液中の硫酸ストロソチウムの溶解度 はクロム酸濃度と浴温に左右され，クロム酸濃度が 250 $\mathrm{g} / l$ で最高の溶解度を示し，また浴温が高くなるほど溶 解度はやや増加する。たとえばクロム酸 $250 \mathrm{~g} / l$ で浴温 が45〜 55ํのクロムメッキ液中での硫酸ストロンチウム の溶解度は $\mathrm{SO}_{4}{ }^{2-}$ として $1.9 \sim 2.0 \mathrm{~g} / l$ である。

2 ）これに炭酸ストロンチウムを添加すれば硫酸スト ロンチウムの溶解度は減少し, 任意の $\mathrm{SO}_{4}{ }^{2-}$ 濃度の自動 制御浴とすることができる。

3）硫酸ストロンチウムの飽和水溶液にストロンチウ ム塩を添加した場合の硫酸ストロンチウムの溶解度の減 少は質量作用の法則で濃度を用いて計算した値とは一致 しない。これは溶液中のイオン強度が増加し活量係数が 低下するためであり，濃度の代わりに活量を用いた計算 をしなくてはならなくなる。

4) しかしながらクロムメッキ液ではストロンチウム 塩の添加による硫酸ストロンチウムの溶解度の減少は濃 度を用いて計算した質量作用の法則を満足する。これは クロムメッキ液中ではクロム酸濃度が高いのでイオン強 度が高く，この中の硫酸ストロンチウムや添加ストロン チウムのイオン強度は無視することができるので活量は いつもクロム酸濃度に比例すると考えてよいからであ る。

(1973-3-19受理)

\section{文献}

1) 小西三郎, 只腰光章, 本誌, 23, 585 (1972)

2 ）小西三郎. 只腰光章, 本誌, 23, 596 (1972)

3 ) 小西三郎, 只腰光章, 本誌, 23, 632 (1972)

4 ) 小西三郎, 只腰光章, 久保田保隆, 本誌, 24, 132 (1973)

5）小西三郎，野村義夫，実務表面技術， $73-2$, p. 65 (1972)

6) H.S. Lukens, USP 2, 042, 611 (1936)

7) J. E. Stareck, USP 2, 640, 022 (1953)

8) L. Dominikov, Metal Finishing, 61, 11, 65 (1963)

9) J. Gabriel, Galvanotechnik, 56, 714 (1965) 
10）小西三郎, 久保田保隆, 本誌, 24，386 (1973)

11) P. Morisset, "Chromium Plating", p. 501, Robert Draper Ltd., (1954)

12) K. L. Langford, Analysis of Electroplating and Related Solutions, p. 40, Robert Drafer Ltd. (1958）など

13）小西三郎, Metal Finishing, 57, 2, 59 (1959)

14) E. Uhling 5, Metalloberfläche, 20, 269 (1966)

15）たとえば化学便ランなど,
16）林禎一,ケイフッ化ナトリウム添加クロムメッキ溶 に関する研究, 学位論文

17) A. Logozzo, Netal Finishing Guidebook \& Directory, p. 250 (1972)

18）堀竜藏，本誌現場パンフレット，69-9, p. 15 (1969)

19) G. Charlot, 曽根与三ら訳, 定性分析化学, I, p. 16, 共立全書（昭46）

20）大塚好治, 分析化学実験, p. 44, 学芸出版（昭39）

\title{
クロムメッキ夜中の $\mathrm{SiF}_{8}$ の自動制御
}

\author{
小西三郎* ・只腰光章 ${ }^{* *} \cdot$ 久保田保隆 ${ }^{* *}$

\section{Chromium Plating Bath for Self-regulating Fluorosilicate \\ Chromium Plating from Low Concentration $\mathrm{CrO}_{3}$ Baths (Part 9) \\ Saburo KONISHI, Mitsuaki TADAGOSHI and Yasutaka KUBOTA}

The self-regulation of fluorosilicate concentration by the addition of $\mathrm{K}^{*}$ to a cirromium plating bath saturated with $\mathrm{K}_{2} \mathrm{SiF}_{6}$ was studied. The following results were obtained: (1) Since $\mathrm{K}_{2} \mathrm{SiF}_{6}$ is a strong acid salt, the solubility of $\mathrm{K}_{2} \mathrm{SiF}_{6}$ in low $\mathrm{pH}$ solution such as a chromium plating bath was not much higher than that in its aqueous solution. (2) The decrease in the solubility of $\mathrm{K}_{2} \mathrm{SiF}_{6}$ conforming to "common-ion effect" did not agree to the following dissociation. $\mathrm{K}_{2}-\mathrm{SiF}_{6} \longrightarrow 2 \mathrm{~K}^{+}+\mathrm{SiF}_{6}{ }^{2-}$. (3) The reason was explained by the following hydrolysis of $\mathrm{K}_{2} \mathrm{SiF}_{6}: \mathrm{K}_{2} \mathrm{SiF}_{6}+\mathrm{H}_{2} \mathrm{O} \longrightarrow 2 \mathrm{~K}^{+}+\mathrm{SiF}_{5}(\mathrm{OH})^{2-}$ $+\mathrm{HF}$. The dissociation of a fluorosilicate having higher solubility such as $\mathrm{Na}_{2} \mathrm{Si}_{6}$ was as follows: $\mathrm{Na}_{2} \mathrm{SiF}_{6} \longrightarrow 2 \mathrm{Na}^{+}+\mathrm{SiF}_{6}{ }^{2-}$. Whereas, the dissociation of a fluorosilicate having lower solubility such as $\mathrm{BaSiF}_{6}$ was as follows: $\mathrm{BaSiF}_{6}+2 \mathrm{H}_{2} \mathrm{O} \longrightarrow \mathrm{Ba}^{2+}+\mathrm{SiF}_{4}(\mathrm{OH})_{2}{ }^{2-}+2 \mathrm{HF}$. The results of experiments well agreed with the basis of these dissociations. (4) For example, the solubility of $\mathrm{K}_{2} \mathrm{SiF}_{6}$ was $10 \mathrm{~g} / \mathrm{l}$ in chromium plating bath containing $250 \mathrm{~g} / l$ of $\mathrm{CrO}_{3}$ at $55^{\circ} \mathrm{C}$. Therefore, the plating bath for selfregulating $\mathrm{SiF}_{6}$ was prepared by the addition of a small amount of $\mathrm{K}_{2} \mathrm{CO}_{3}$ to the bath. The solubility of $\mathrm{K}_{2} \mathrm{SiF}_{6}$ was $7 \mathrm{~g} / \mathrm{l}$ in low concentration chromium plating bath containing $50 \mathrm{~g} / \mathrm{l}$ of $\mathrm{CrO}_{3}$ at $55^{\circ} \mathrm{C}$. Since the optimum concentration of $\mathrm{K}_{2} \mathrm{SiF}_{6}$ in this bath is $0.6 \mathrm{~g} / l, 27.5 \mathrm{~g} / l$ of $\mathrm{K}_{2} \mathrm{CO}_{3}$ shall be added to get the self-regulating bath. However, this composition was not adequate for the chromium plating bath owing to the increase of $\mathrm{pH}$ value.

† 低濃度クロム酸溶液からのクロムメッキに関する研究 （第 9 報），前報(第 8 報）：金属表面技術, 24,449（1973）

* 大阪府立工業技術研究所（大阪府東大阪市高井田中 1 -38)

Industrial Research Institute Osaka Prefecture

**奥野製薬工業(株)（大阪府大阪市城東区放出町中 1 38) Okuno Chemical Industry Co., Ltd.

\section{1. ま え がき}

$\mathrm{SiF}_{6}{ }^{2-}$ の自動制御クロムメッキ浴としてはSRHS浴 ${ }^{1) ~}$ 3)が有名である。これはよく知られているよらに, 高濃度 クロムメッキ液に硫酸ストロンチウムとケイフッ化カリ ウムを溶解度以上加え, さらに一定量のストロンチウム 塩とカリウム塩を添加することによって $\mathrm{SO}_{4}{ }^{2-}$ と $\mathrm{SiF}_{6}{ }^{2-}$ 濃度をある適量に自動制御したクロムメッキ浴である。 